\title{
Pengaruh Tenaga Kerja, Modal Dan Luas Lahan Terhadap Produksi Usaha Tani Tebu Di Kecamatan Ngadiluwih Kabupaten Kediri
}

\author{
Moh. Rozi ${ }^{1)}$ Abu Talkah ${ }^{2)}$ Ahsin Daroini ${ }^{3)}$ \\ 1,2,3 Magister Agribisnis, Universitas Islam Kadiri
}

\begin{abstract}
The purpose of this study are: (1) to know the effect of land area to the production of sugarcane farming business at Ngadiluwih-Kediri; (2) To know the effect of capital on sugarcane farm production at Ngadiluwih-Kediri; (3) To know the influence of labors on the production of sugarcane farming business in Ngadiluwih-Kediri; (4) to know the influence of land area, capital and labors simultanously to production of sugarcane farming business in Ngadiluwih-Kediri; (5) to know the most dominant influence of variable land area, labor and capital to the production of sugarcane farming business in Ngadiluwih Kediri.

Population used in this research is sugar cane farmer in Ngadiluwih-Kediri Regency. This study uses Proportional Stratified Random Sampling. This technique is used when the population has non-homogeneous elements and is taken randomly, but proportionately. By utilizing Slovin formulations in the sampling with the accuracy of $10 \%$ obtained 95 respondents. This study uses instruments that have been developed by previous researchers. The instrument used is a questionnaire with Likert scale 5 for each research variable.

The results showed that: (1) Labor has a positive influence on the production of sugarcane farming in Ngadiluwih Kediri Regency. (2) Capital significantly has a positive influence on the production of sugarcane farming in Ngadiluwih Kediri Regency. (3) Land area significantly has a positive influence on the production of sugarcane farming business in Ngadiluwih Kediri Regency. (4) Together labor, capital and land area have a positive effect on the production of sugar cane farming business in Ngadiluwih Kediri Regency. (5) The result of dominance test analysis to know the effective contribution shows that capital has the most dominant contribution in influencing the production of sugarcane farming business in Ngadiluwih Kediri Regency.
\end{abstract}

Keywords: Labors, Capital, Land, Productivity, Sugarcane farming.

\section{Pendahuluan}

\begin{tabular}{llrr} 
Tebu & \multicolumn{2}{c}{ (Sacharum } & officinarum) \\
merupakan & salah satu & komoditas \\
penghasil & gula & yang & mampu
\end{tabular} meningkatkan perekonomian Indonesia. Guna mempertahankan produktivitas tebu pemerintah berupaya menggalakkan penanaman tebu untuk mengatasi rendahnya produksi gula di Indonesia. Adapun alasan pemerintah untuk memperhatikan perkebunan tebu adalah karena pertambahan jumlah permintaan akan gula semakin meningkat, pendapatan penduduk yang rendah akibat kurangnya lapangan pekerjaan serta pola konsumsi masyarakat meningkat semakin membutuhkan gula.

Dengan luas areal usahatani tebu sekarang sekitar 400.000 ha. Jawa menguasai sekitar $61,87 \%$ (277.630 ha) dari luas seluruh area perkebunan tebu dan sisanya $38,13 \%$ di luar Jawa seluas 171.115 ha. Industri gula berbasis tebu merupakan salah satu sumber pendapatan bagi sekitar 900 ribu petani dengan jumlah tenaga kerja yang terlibat mencapai sekitar 1,3 juta orang (Dewan Gula Indonesia, 2012). Area potensial untuk ditanami tebu di Indonesia lebih dari separuhnya terdapat di Jawa. Gula juga merupakan salah satu kebutuhan pokok masyarakat yang terus meningkat seiring dengan pertambahan jumlah penduduk. Namun peningkatan konsumsi gula belum dapat diimbangi oleh produksi gula dalam negeri. Karena merupakan kebutuhan pokok, maka dinamika harga gula akan mempunyai pengaruh langsung terhadap laju inflasi.

Di Indonesia konsumsi gula terus mengalami peningkatan setiap tahunnya. Pada tahun 2016, kebutuhan gula nasional diperkirakan 3 juta ton per tahun untuk konsumsi masyarakat. Data Ditjen Perkebunan Kementan mencatat produksi gula pada tahun 2015 sebesar 2,5 juta 
ton. Tahun 2016 Produksi Gula Menurun, Asosiasi Gula Indonesia (AGI) mencatat produksi gula tahun 2016 hanya sebesar 2,4 juta ton. Penurunan produksi setiap tahun disebabkan karena faktor iklim dan terjadi penurunan areal tanaman tebu. Menurut Gde, 2017 produksi gula nasional bisa ditingkatkan dengan menambah luas areal tanam dan produktivitas tanaman tebu. Rendemen tanaman tebu petani berkisar antara 7-8\%. Namun, untuk tahun ini target rendemen sebesar $8 \%$. Oleh karena itu, Indonesia masih sulit untuk memenuhi kebutuhan gula konsumsi masyarakat.

Fenomena yang terjadi di PTPN XI (Persero) yang mengelola 16 Pabrik Gula dan mempunyai kontribusi sekitar 18\% dari produksi gula nasional, dalam kurun waktu 10 tahun produksi gula mengalami fluktuasi dan cenderung menurun. Pada 10 tahun terakhir, produksi gula secara umum mengalami peningkatan sekitar $2,2 \%$ setiap tahunnya, namun sampai saat ini belum mampu memenuhi kebutuhan gula, sehingga sisanya dipenuhi dengan mengimpor. Peningkatan produksi gula belum mampu memenuhi kebutuhan konsumen gula. sehingga pemerintah melakukan impor gula untuk memenuhi konsumsi gula yang tidak dapat dipenuhi oleh produksi gula Indonesia. Oleh karena itu, pemerintah terus berupaya untuk meningkatkan produksi gula agar mampu memenuhi kebutuhan konsumen, sehingga pemenuhan konsumsi gula tidak terlalu tergantung kepada impor.

Dengan posisinya yang penting dan sejalan dengan revitalisasi sektor pertanian, maka industri gula berbasis tebu juga perlu melakukan berbagai upaya sehingga sejalan dengan revitalisasi sektor pertanian. Hal ini menuntut industri gula berbasis tebu perlu melakukan berbagai perubahan guna meningkatkan produktivitas dan efisiensi produksi, sehingga menjadi industri yang kompetitif dan meningkatkan pendapatan masyarakat. Sejalan dengan hal tersebut, tulisan ini dimaksudkan untuk memberikan gambaran peluang investasi pada industri berbasis gula agar bisa meningkatkan pendapatan masyarakat. Informasi ini dapat menjadi acuan pemerintah dan pelaku bisnis dalam merumuskan kebijakan dan program investasi pada industri gula berbasis tebu.

Pengembangan usahatani tebu diharapkan dapat meningkatkan pendapatan dan taraf hidup petani serta memacu percepatan swasembada gula secara nasional atau mengurangi ketergantungan terhadap impor gula. Saat ini Indonesia menjadi salah satu negara pengimpor gula di dunia. Produksi gula di Indonesia mengalami pasang surut sampai akhirnya Indonesia menjadi negara pengimpor gula sejak tahun 1967 sampai sekarang. Hal ini dikarenakan produksi gula Indonesia tidak dapat memenuhi kebutuhan gula yang terus meningkat setiap tahunnya. Pada 10 tahun terakhir, produksi gula secara umum mengalami peningkatan sekitar 2,2 persen setiap tahunnya, namun sampai saat ini belum mampu memenuhi kebutuhan gula sehingga sisanya dipenuhi dengan mengimpor. Oleh karena itu, pemerintah terus berupaya untuk meningkatkan produksi gula agar mampu memenuhi kebutuhan konsumen, sehingga pemenuhan konsumsi gula tidak terlalu tergantung kepada impor.

Kabupaten Kediri merupakan daerah yang memiliki potensi sebagian besar lahannya sudah dimanfaatkan untuk ditanami komoditas tanaman tebu. Tinggi rendahnya tingkat pendapatan petani tebu dapat dipengaruhi oleh beberapa faktor. Dalam penelitian ini terutama di Kabupaten Kediri adalah jumlah luas lahan yang berbeda-beda. Modal usahatani yang merupakan salah satu faktor produksi dalam bentuk dana maupun perlengkapan. Biaya tenaga kerja yang dinyatakan dalam hari orang kerja (HOK) setiap petani berbeda dalam pengelolaannya dan harga dari Pabrik. Karena hasil usahatani tebu yang hanya bisa diperoleh sekali dalam setahun maka perlu diketahui faktor-faktor yang mampu mempengaruhi pendapatan petani tebu. Berdasarkan latar belakang di atas peneliti mencoba untuk melakukan penelitian tentang pendapatan petani tebu keprasan. Penelitian ini dilakukan untuk melihat keuntungan usahatani tebu keprasan dengan cara membandingkan variasi 
usahatani tebu di Kecamatan Ngadiluwih Kabupaten Kediri. Variasi tersebut antara lain luas lahan kurang dari satu hektar dan luas lebih dari satu hektar.

\section{Metode Penelitian \\ Rancangan Jenis Penelitian}

Jenis pendekatan penelitian yang digunakan dalam penelitian ini adalah kuantitatif deskriptif. Metode penelitian kuantitatif deskriptif dimaksudkan untuk menjelaskan suatu generalisasi sampel terhadap populasinya atau menjelaskan hubungan, perbedaan atau pengaruh variabel terhadap variabel lainnya. Priyono (2016:37) menyatakan bahwa penelitian kuantitatif deskriptif dilakukan untuk memberikan gambaran yang lebih detail mengenai suatu gejala dan fenomena. Hasil akhir dari penelitian ini berupa tipologi atau pola-pola mengenai fenomena yang sedang dibahas.

Pendekatan kuantitatif juga digunakan untuk mengembangkan dan menyempurnakan teori dan memiliki kredibilitas untuk mengukur, menguji hubungan sebab-akibat dari dua atau beberapa variabel dengan menggunakan analisis statistik (Arikunto, 2013:234). Desain formal diperlukan untuk meyakinkan bahwa deskripsi mencakup semua tahapan yang diinginkan untuk mencegah dikumpulkannya data yang tidak perlu. Penelitian deskriptif berupaya untuk memperoleh penjelasan atau deskripsi yang lengkap dan akurat dari sebuah situasi (Rahmat, 2013:33).

Populasi adalah wilayah generalisasi yang terdiri atas obyek dan subyek yang mempunyai kualitas atau karakteristik tertentu yang ditetapkan oleh peneliti untuk dipelajari dan ditarik kesimpulannya (Sugiyono, 2014:61). Populasi yang digunakan dalam penelitian ini adalah petani tebu di Kecamatan Ngadiluwih Kabupaten Kediri. Sampel adalah bagian dari sejumlah dan karakteristik yang dimiliki oleh populasi (Sugiyono, 2014: 62).

Penelitian ini menggunakan Proportional Stratified Random Sampling. Teknik ini digunakan bila populasi mempunyai anggota/unsur yang tidak homogen dan diambil secara acak, namun proporsional. Jika kondisi populasi mengandung sejumlah kategori yang berbeda, kerangka sampel dapat diorganisasi dengan menggunakan kategori yang terpisah. Cara penarikan sampel dilakukan dengan menyeleksi setiap unit sampling yang sesuai dengan ukuran unit sampling (Rahmat, 2013:122). Dengan memanfaatkan formulasi Slovin (Rahmat, 2013) dalam penarikan jumlah sampel dengan ketelitian $10 \%$ didapatkan 95 reponden yang harus diambil datanya.

Penelitian ini menggunakan instrumen yang telah dikembangkan peneliti sebelumnya. Instrumen yang digunakan berupa kuesioner dengan skala Likert untuk setiap variabel penelitian. Pengukuran dalam penelitian ini menggunakan data interval dengan skala Likert 1 sampai dengan 5. Dalam skala ini, angka 1 (satu) menunjukkan bahwa responden memberikan tanggapan sangat tidak setuju terhadap pernyataan yang diajukan, sedangkan angka 5 (lima) menunjukkan sangat setuju.

Metode pengumpulan data yang digunakan dalam penelitian ini adalah metode angket atau metode kuesioner. Metode angket merupakan daftar pertanyaan atau pernyataan yang disusun secara sistematis, kemudian diisi oleh responden. Metode angket yang digunakan adalah angket tertutup, yaitu angket yang dirancang sedemikian rupa untuk merekam data tentang keadaan yang dialami responden, kemudian semua pertanyaan harus dijawab sesuai dengan pilihan alternatif jawaban yang telah tertera dalam angket tersebut.

Pengukuran validitas dari masingmasing alat pengambil data (kuesioner), dilakukan dengan cara mengkorelasi skor item butir pertanyaan terhadap total skor pada setiap faktor dari masing-masing responden yang diujicoba. Korelasi yang dibentuk berdasarkan teknik korelasi product moment yang formulasi matematisnya menurut Arikunto (2013:327).

Uji reliabilitas dapat dilakukan dengan menghitungan nilai Alpha. Jika hasil perhitungan $r$ Alpha positif dan $r$ Alpha $>r$ tabel maka butir atau variabel 
tersebut reliabel. Sebaliknya, bila $r$ Alpha $<r$ tabel maka butir atau variabel tersebut tidak reliabel. Dalam SPSS 16.0 pengukuran reliabilitas menggunakan Alpha Cronbach > 0,60.

\section{Analisis Dan Pembahasan}

Pengujian hipotesis dilakukan dengan analisis regresi berganda. Analisis regresi berganda digunakan untuk menguji hipotesis pengaruh antar variabel secara terpisah/parsial maupun untuk menguji pengaruh varial secara simultan/bersamasama. Berdasarkan analisis regresi berganda dengan memanfaatkan program SPSS for Windows 16.0 diperoleh hasil sebagaimana tabel 1 dibawah ini:

Tabel 1. Ringkasan Hasil Analisis Regresi

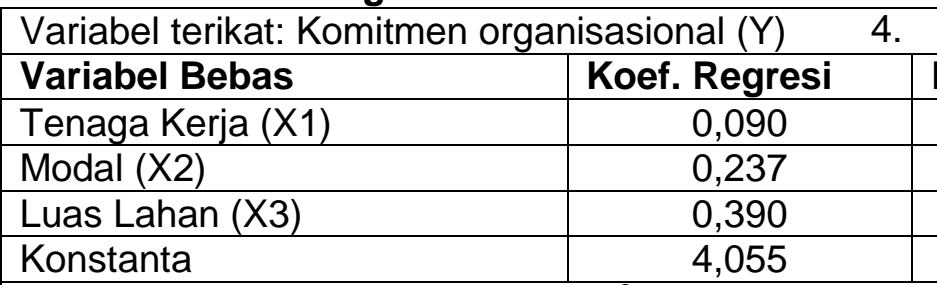

Koefisien Determinasi Berganda $\left(R^{2}\right)=0,350$

Koefisien Korelasi Berganda $(R)=0,591$

F-statistik $=10,748$

Durbin-Watson Statistik $=2,043$

Sumber: data primer diolah, 2017

\section{Model Regresi}

Dari hasil analisis statistik sebagaimana ringkasan hasil analisis regresi pada tabel 1. Diatas dapat disusun rumusan fungsi atau persamaan seperti dibawah ini:

$$
\begin{aligned}
& \text { PUTT }=4,055+0,090 . T T+ \\
& 0,237 . M+0,390 \cdot L L+\varepsilon \\
& R^{2}=0,350
\end{aligned}
$$

Dari persamaan tersebut selanjutnya dapat diinterpretasikan untuk besarnya nilai dari tiap-tiap koefesien regresi sebagai berikut:

1. Konstanta $(\beta 0=4,055)$ menunjukkan bahwa jika kondisi dimana variabel tenaga kerja, modal dan luas lahan dianggap tetap dan bernilai nol, maka produksi usaha tani tebu adalah sebesar 4,055.

2. Koefisien regresi variabel tenaga kerja $(\beta 1=0,090)$ memberikan makna bahwa pada kondisi ceteris paribus, jika skor rata-rata tenaga kerja meningkat sebesar satu satuan, maka skor rata-rata produksi usaha tani tebu akan meningkat sebesar 0,090 satuan. Besarnya nilai koefisien regresi positif memberikan makna bahwa tenaga kerja mempunyai pengaruh positif terhadap produksi usaha tani tebu.

3. Koefisien regresi variabel modal ( $\beta 2=$ $0,237)$ memberikan makna bahwa pada kondisi ceteris paribus, jika skor rata-rata modal meningkat sebesar satu satuan, maka skor rata-rata produksi usaha tani tebu akan meningkat sebesar 0,237 satuan. Besarnya nilai koefisien regresi positif memberikan makna bahwa modal mempunyai pengaruh positif terhadap produksi usaha tani tebu.

Koefisien regresi variabel iklim
KoefuBiterai $(\beta 3=$ D-Basib memberikan makroa1

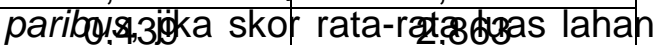

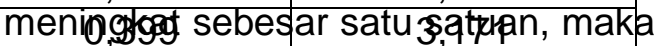
skor rata-rata produksi usaha tani tebu akan meningkat sebesar 0,390 satuan. Besarnya nilai koefisien regresi positif memberikan makna bahwa luas lahan mempunyai pengaruh positif terhadap produksi usaha tani tebu.

5. Nilai koefisien determinasi berganda yang ditunjukkan oleh besarnya nilai $R^{2}=0,350$ menunjukkan besarnya produksi usaha tani tebu Kecamatan Ngadiluwih Kabupaten Kediri sekitar $35,0 \%$ ditentukan oleh perubahan variabel bebas tenaga kerja, modal dan luas lahan.

\section{Pengujian Hipotesis Secara Terpisah}

Pengaruh ketiga varibel bebas yang terdiri dari variabel tenaga kerja, modal dan luas lahan terhadap produksi usaha tani tebu Kecamatan Ngadiluwih Kabupaten Kediri secara terpisah diukur dari nilai koefisien regresinya. Jika koefisien regresi positif maka pengaruhnya positif, sebaliknya jika koefisiennya negatif maka berpengaruh negatif. Untuk mengetahui apakah pengaruh tersebut signifikan atau tidak, 
diukur dari nilai t-hitung atau t-ratio masing-masing variabel bebas. Jika thitung lebih besar dari t-tabel, maka berarti pengaruh tersebut signifikan, begitu sebaliknya. Berdasarkan uji statistik tersebut dapat menghasilkan variasi simpulan suatu variabel: berpengaruh positif dan signifikan, berpengaruh positif tapi tidak signifikan, berpengaruh negatif dan signifikan, serta berpengaruh negatif tetapi tidak signifikan.

a) Pengaruh variabel tenaga kerja (X1) terhadap produksi usaha tani tebu (Y)

Koefisien regresi variabel tenaga kerja $(\beta 1=0,090)$ memberikan makna bahwa pada kondisi ceteris paribus, jika skor rata-rata tenaga kerja meningkat sebesar satu satuan, maka skor ratarata produksi usaha tani tebu akan meningkat sebesar 0,090 satuan. Besarnya nilai koefisien regresi positif memberikan makna bahwa tenaga kerja mempunyai pengaruh positif terhadap produksi usaha tani tebu Kecamatan Ngadiluwih Kabupaten Kediri.

Untuk mengetahui signifikan pengaruh variabel tenaga kerja terhadap produksi usaha tani tebu, maka langkah selanjutnya adalah melakukan pengujian hipotesis. Langkah-langkah pengujiannya adalah:

a. Menentukan Hipotesis

$$
\begin{aligned}
& \text { Ho : } \beta 1=0 \text {, secara terpisah } \\
& \text { variabel tenaga } \\
& \text { kerja tidak } \\
& \text { mempunyai } \\
& \text { pengaruh yang } \\
& \text { signifikan terhadap } \\
& \text { variabel produksi } \\
& \text { usaha tani tebu. }
\end{aligned}
$$

$\mathrm{Ha}: \beta 1 \neq 0$, secara terpisah variabel tenaga kerja mempunyai pengaruh yang signifikan terhadap variabel produksi usaha tani tebu.

b. Menghitung harga statistik

Dari hasil analisis regresi diperoleh nilai t-statistik sebesar 1,055 dengan taraf signifikansi $5 \%$ dan derajat kebebasan $(\mathrm{df})=95-1-3$
= 91 diperoleh harga $t$ dalam tabel $=1,662$.

c. Kesimpulan

Karena harga t-hitung $=1,055$ lebih kecil dari harga t-tabel $=1,662$, maka harga t-hitung berada di daerah penolakan Ho, maka kesimpulannya hipotesis menolak Ho, yang artinya bahwa secara terpisah variabel tenaga kerja mempunyai pengaruh positif dan tetapi tidak signifikan terhadap produksi usaha tani tebu Kecamatan Ngadiluwih Kabupaten Kediri.

Dari hasil analisis tersebut baik analisis regresi maupun pengujian statistik membuktikan hipotesis yang mengatakan bahwa variabel tenaga kerja mempunyai pengaruh positif namun tidak signifikan terhadap produksi usaha tani tebu.

\section{b) Pengaruh variabel modal (X2) terhadap produksi usaha tani tebu (Y)}

Koefisien regresi variabel modal $(\beta 2=0,237)$ memberikan makna bahwa pada kondisi ceteris paribus, jika skor rata-rata modal meningkat sebesar satu satuan, maka skor ratarata produksi usaha tani tebu akan meningkat sebesar 0,237 satuan. Besarnya nilai koefisien regresi positif memberikan makna bahwa modal mempunyai pengaruh positif terhadap produksi usaha tani tebu Kecamatan Ngadiluwih Kabupaten Kediri.

Untuk mengetahui signifikan pengaruh variabel modal terhadap produksi usaha tani tebu, maka langkah selanjutnya adalah melakukan pengujian hipotesis. Langkah-langkah pengujiannya adalah:

a. Menentukan Hipotesis

$$
\begin{aligned}
\text { Ho : } \beta 2= & 0, \text { secara terpisah } \\
& \text { variabel modal } \\
& \text { tidak mempunyai } \\
& \text { pengaruh yang } \\
& \text { signifikan terhadap } \\
& \text { variabel produksi } \\
& \text { usaha tani tebu. } \\
\mathrm{Ha}: \beta 2 \neq & 0, \text { secara terpisah } \\
& \text { variabel modal }
\end{aligned}
$$


mempunyai

pengaruh yang

signifikan terhadap

variabel produksi

usaha tani tebu.

b. Menghitung harga statistik

Dari hasil analisis regresi diperoleh nilai t-statistik sebesar 2,863 dengan taraf signifikansi 5\% dan derajat kebebasan (df) $=95-$ $1-3=91$ diperoleh harga $t$ dalam tabel $=1,662$.

c. Kesimpulan

Karena harga t-hitung $=2,863$ lebih besar dari harga t-tabel = 1,662, maka harga t-hitung tetap berada di daerah penolakan Ho, maka kesimpulannya hipotesis menolak Ho, yang artinya bahwa secara terpisah variabel modal mempunyai pengaruh positif dan signifikan terhadap produksi usaha tani tebu Kecamatan Ngadiluwih Kabupaten Kediri.

Dari hasil analisis tersebut baik analisis regresi maupun pengujian statistik membuktikan hipotesis yang mengatakan bahwa variabel modal mempunyai pengaruh yang positif dan signifikan terhadap produksi usaha tani tebu.

c) Pengaruh variabel luas lahan (X3) terhadap produksi usaha tani tebu (Y)

Koefisien regresi variabel luas lahan $(\beta 3=0,390)$ memberikan makna bahwa pada kondisi ceteris paribus, jika skor rata-rata luas lahan meningkat sebesar satu satuan, maka skor rata-rata produksi usaha tani tebu akan meningkat sebesar 0,390 satuan. Besarnya nilai koefisien regresi positif memberikan makna bahwa luas lahan mempunyai pengaruh positif terhadap produksi usaha tani tebu Kecamatan Ngadiluwih Kabupaten Kediri.

Untuk mengetahui signifikan pengaruh variabel luas lahan terhadap produksi usaha tani tebu, maka langkah selanjutnya adalah melakukan pengujian hipotesis. Langkah-langkah pengujiannya adalah:

a. Menentukan Hipotesis
Ho : $\beta 3=0$, secara terpisah variabel luas lahan tidak mempunyai pengaruh yang signifikan terhadap variabel produksi usaha tani tebu.

$\mathrm{Ha}$ : $\beta 3 \neq 0$, secara terpisah variabel luas lahan mempunyai pengaruh yang signifikan terhadap variabel produksi usaha tani tebu.

b. Menghitung harga statistik

Dari hasil analisis regresi diperoleh nilai t-statistik sebesar 3,171 dengan taraf signifikansi 5\% dan derajat kebebasan (df) $=95-$ $1-3=91$ diperoleh harga $t$ dalam tabel $=1,662$.

c. Kesimpulan

Karena harga t-hitung $=3,171$ lebih besar dari harga t-tabel = 1,662, maka harga t-hitung berada di daerah penolakan Ho, maka kesimpulannya hipotesis menolak Ho, yang artinya bahwa secara terpisah variabel luas lahan mempunyai pengaruh positif dan signifikan terhadap produksi usaha tani tebu Kecamatan Ngadiluwih Kabupaten Kediri.

Dari hasil analisis tersebut baik analisis regresi maupun pengujian statistik membuktikan hipotesis yang mengatakan bahwa variabel luas lahan mempunyai pengaruh yang positif dan signifikan terhadap produksi usaha tani tebu.

\section{Pengujian Hipotesis Secara Bersama- sama}

Pengujian ini bertujuan untuk membuktikan apakah hipotesis yang mengatakan bahwa secara bersama-sama tenaga kerja, modal dan luas lahan berpengaruh positif dan signifikan terhadap produksi usaha tani tebu Kecamatan Ngadiluwih Kabupaten Kediri. Uraian hipotesis tersebut kemudian dibuktikan dengan melakukan pengujian statistik dengan uji F.

Hasil pengolahan data dengan perhitungan perangkat lunak program komputer SPSS Versi 16.0 for Windows 
dihasilkan F-hitung sebesar 10,748. Dengan menggunakan taraf signifikasi (alpha: $5 \%$ ), dan daerah kritis df = 3 dan $\mathrm{N}$ = 95 menghasilkan F-tabel sebesar 2,70.

Hasil pengujian tersebut menunjukkan bahwa F-hitung 10,748 > Ftabel 2,70 yang bermakna secara bersama-sama variabel tenaga kerja, modal dan luas lahan mempunyai pengaruh yang signifikan terhadap produksi usaha tani tebu Kecamatan Ngadiluwih Kabupaten Kediri.

\section{Perbandingan Nilai dari Pengaruh Masing-masing Variabel}

Untuk mengetahui urutan pengaruh terbesar variabel bebas tenaga kerja, modal dan luas lahan terhadap produksi usaha tani tebu dapat menggunakan perkalian nilai koefisien beta (standardized) dengan koefisien korelasi Pearson dari masing-masing variabel bebas. Hasil penjumlahan dari perkalian tersebut menunjukkan nilai $R$ square. Tabel 4.12 berikut merupakan perhitungan urutan kontribusi pengaruh ketiga variabel terhadap produksi usaha tani tebu adalah sebagai berikut:

\section{Tabel Perbandingan nilai dan urutan pengaruh masing-masing variabel}

\begin{tabular}{|l|l|l|l|l|}
\hline $\begin{array}{l}\text { Vari } \\
\text { abel } \\
\text { Beb } \\
\text { as }\end{array}$ & $\begin{array}{l}\text { Koefisi } \\
\text { en Beta } \\
\text { (Standa } \\
\text { rdized) }\end{array}$ & $\begin{array}{l}\text { Koefi } \\
\text { sien } \\
\text { Correl } \\
\text { ation } \\
\text { Pears } \\
\text { on }\end{array}$ & $\begin{array}{l}\text { Hasil } \\
\text { Perk } \\
\text { alian }\end{array}$ & $\begin{array}{l}\text { Keter } \\
\text { angan }\end{array}$ \\
\hline $\begin{array}{l}\text { Ten } \\
\text { aga } \\
\text { Kerj } \\
\text { a } \\
\text { (X1) }\end{array}$ & 0,175 & 0,135 & $\begin{array}{l}0,043 \\
63\end{array}$ & $\begin{array}{l}\text { Urutan } \\
\text { ke-3 }\end{array}$ \\
\hline $\begin{array}{l}\text { Mod } \\
\text { al } \\
\text { (X2) }\end{array}$ & 0,439 & 0,347 & $\begin{array}{l}\text { atau } \\
\text { atau }\end{array}$ & $\begin{array}{l}\text { Urutan } \\
\text { ke-1 }\end{array}$ \\
\hline $\begin{array}{l}\text { Lua } \\
\text { S } \\
\text { Lah } \\
\text { an } \\
\text { (X3) }\end{array}$ & 0,399 & 0,379 & $\begin{array}{l}15,23 \\
3 \%\end{array}$ & \\
\hline
\end{tabular}

\begin{tabular}{|l|l|l|}
\hline & 0,350 & \\
Jumlah & atau & \\
& 35,0 & \\
$\%$ & \\
\hline
\end{tabular}

Sumber: data primer diolah, 2017.

Berdasarkan Tabel 2 dapat diinterpretasikan sebagai berikut:

a) Variabel Modal dengan nilai koefisien beta (standardized) 0,439 dan nilai koefisien korelasi pearson sebesar 0,347 setelah dikalikan memberikan hasil 0,15233 . Hal ini memberikan arti bahwa kontribusi efektif Modal terhadap produksi usaha tani tebu Kecamatan Ngadiluwih Kabupaten Kediri sebesar 15,233\%.

b) Variabel Luas Lahan dengan nilai koefisien beta (standardized) 0,399 dan nilai koefisien korelasi pearson sebesar 0,379 setelah dikalikan memberikan hasil 0,15122 . Hal ini memberikan arti bahwa kontribusi efektif luas lahan terhadap produksi usaha tani tebu Kecamatan Ngadiluwih Kabupaten Kediri sebesar $15,122 \%$.

c) Variabel Tenaga Kerja dengan nilai koefisien beta (standardized) 0,175 dan nilai koefisien korelasi pearson sebesar 0,135 setelah dikalikan memberikan hasil 0,04363. Hal ini memberikan arti bahwa kontribusi efektif tenaga kerja terhadap Kecamatan Ngadiluwih Kabupaten Kediri sebesar 4,363\%.

Berdasarkan perhitungan dapat disimpulkan bahwa Variabel Modal memberikan kontribusi pengaruh paling dominan dibandingkan variabel tenaga kerja dan luas lahan terhadap produksi usaha tani tebu Kecamatan Ngadiluwih Kabupaten Kediri.

\section{Implikasi Hasil Penelitian}

Deskripsi Tenaga Kerja, Modal, Luas Lahan dan Produksi Usaha Tani Tebu di Kecamatan Ngadiluwih Kabupaten Kediri. Berdasarkan hasil penelitian dengan menggunakan alat analisis deskriptif dapat dibahas sebagai berikut:

\section{a. Tenaga Kerja}


Berdasarkan data hasil penelitian dari variabel tenaga kerja yaitu dengan pemakaian jumlah tenaga kerja serta curahan kerja dengan satuan banyaknya tenaga kerja (orang) yang dipakai untuk proses produksi menunjukkan bahwa rata-rata skor variabel tenaga kerja di Kecamatan Ngadiluwih adalah 27,50 dengan persentase $57 \%$ dengan kriteria sedikit. Salah satu penyebab minimnya penggunaan tenaga kerja karena ketersediaan tenaga kerja yang relatif sedikit. Setelah terjadinya industrialisasi yang ditandai oleh dimulainya revolusi hijau pada dasawarsa tujuh puluhan. Peningkatan produktivitas semakin tidak bisa atau sulit ditingkatkan karena tenaga kerja yang tersisa hanyalah tenaga yang berusia lanjut dan wanita. Sementara tenaga muda yang lebih banyak tidak berminat pada sector pertanian tebu karena lebih tertarik pada sector industri di perkotaan.

Kriteria deskriptif persentase untuk variabel tenaga kerja dilihat dari pemakaian jumlah tenaga kerja (orang) dan curahan kerja menunjukkan bahwa ada 4 petani yang menyatakan tenaga kerja yang dipakai termasuk pada kriteria banyak, ada 11 petani yang menyatakan penggunaan tenaga kerjanya termasuk pada kriteria cukup banyak, ada 75 petani yang menyatakan bahwa pengguna tenaga kerjanya termasuk pada kriteria sedikit, dan ada 5 petani yang menyatakan bahwa penggunaan tenaga kerjanya termasuk pada kriteria sangat sedikit.

\section{b. Modal}

Berdasarkan data hasil
penelitian variabel modal yaitu
pemakaian biaya tenaga kerja dan
biaya bahan produksi dengan satuan
rupiah menunjukkan bahwa rata-rata
skor variabel modal pada usaha tani
tebu di Kecamatan Ngadiluwih adalah
23,64 dengan persentase $67 \%$ dan
termasuk kriteria cukup tinggi
pemakaian modal atau biaya yang
dikeluarkan. Modal adalah faktor
terpenting dalam pertanian khususnya

terkait bahan produksi dan biaya tenaga kerja. Dengan kata lain, keberadaan modal sangat menentukan tingkat atau macam teknologi yang diterapkan. Kekurangan modal menyebabkan kurangnya masukan yang diberikan sehingga menimbulkan resiko kegagalan atau rendahnya hasil yang akan diterima.

Kriteria deskriptif persentase untuk variabel modal menunjukkan bahwa ada 5 petani yang menyatakan bahwa modal yang dikeluarkan untuk biaya tenaga kerja dan biaya bahan produksi termasuk pada penggunaan dengan kriteria tinggi, ada 57 petani yang menyatakan bahwa modal yang dikeluarkan untuk biaya tenaga kerja dan biaya bahan produksi termasuk pada penggunaan dengan kriteria cukup tinggi, ada 30 petani yang menyatakan bahwa modal yang digunakan untuk biaya tenaga kerja dan biaya bahan produksi termasuk pada penggunaan dengan kriteria rendah dan ada 3 petani yang menyatakan bahwa modal yang digunakan untuk biaya tenaga kerja dan biaya bahan produksi termasuk pada penggunaan dengan kriteria sangat rendah.

\section{c. Luas Lahan}

Berdasarkan data hasil penelitian variabel luas lahan yaitu luas tanah garapan petani yang digunakan untuk menanam tebu dengan satuan hektare menunjukkan bahwa rata-rata skor luas lahan pada usaha tani padi sawah di Kecamatan Ngadiluwih adalah 2,78 dengan persentase $70 \%$ dan termasuk kriteria cukup luas. Lahan pertanian merupakan penentu dari pengaruh komoditas pertanian. Secara umum dikatakan, semakin luas lahan (yang digarap/ditanami), semakin besar jumlah produksi yang dihasilkan oleh lahan tersebut. Pengaruh luas lahan tidak hanya pada tingkat efisiensi usaha tani saja, tetapi juga mempunyai dampak pada upaya transfer dan penerapan teknologi dalam pembangunan pertanian. Bila 
pemilikan lahan lebih banyak secara kotak-kotak dengan luas penguasaan yang sempit, upaya pembangunan pertanian akan sulit dilakukan. Petani biasanya lebih menguasai lahannya daripada bekerja menurut kemauan bersama. Artinya, kurangnya motivasi untuk bekerjasama dan menantang resiko menyebabkan petani bertindak sendiri-sendiri. Tetapi bila penguasaan lahan cukup luas, umpamanya pada kasus lahan sawah rata-rata diatas satu hektare per petani, proses transfer teknologi akan lebih mudah.

Kriteria deskriptif persentase untuk variabel luas lahan yaitu luas tanah garapan yang dipakai untuk bercocok tanam padi sawah dengan satuan hektare menunjukkan bahwa ada 22 petani yang menyatakan bahwa luas lahan yang digarapnya termasuk pada kriteria luas, ada 44 petani yang menyatakan bahwa luas lahan yang digarapnya termasuk pada kriteria cukup luas, ada 23 petani yang menyatakan bahwa luas lahan yang digarapnya termasuk pada kriteria sempit, dan ada 6 petani yang menyatakan bahwa luas lahan yang digarapnya termasuk pada kriteria sangat sempit.

\section{d. Produksi Tani Tebu di Kecamatan Ngadiluwih}

Berdasarkan data hasil penelitian variabel produksi usaha tani padi sawah yaitu besarnya hasil produksi tani tebu setelah panen dengan satuan ton dan rupiah $(R p)$ menunjukkan bahwa rata-rata skor produksi tani tebu di Kecamatan Ngadiluwih Kabupaten Kediri adalah 6,35 dengan persentase $68 \%$ dan termasuk kriteria cukup tinggi. Didalam produksi pertanian, faktor produksi memang menentukan besar kecilnya produksi yang akan diperoleh. Untuk menghasilkan produksi (output) yang optimal maka penggunaan faktor produksi tersebut dapat digabungkan. Dalam berbagai literatur menunjukkan bahwa faktor produksi lahan, modal untuk membeli bibit, pupuk, obatobatan, tenaga kerja dan aspek manajemen adalah faktor produksi terpenting diantara faktor produksi yang lain, seperti tingkat pendidikan, tingkat pendapatan, tingkat ketrampilan dan lain-lain.

Kriteria deskriptif persentase untuk variabel produksi usaha tani menunjukkan bahwa ada 19 petani yang menyatakan bahwa hasil produksi usaha tani tebu termasuk pada kriteria tinggi, ada 30 petani yang menyatakan bahwa hasil produksi usaha tani tebu termasuk pada kriteria cukup tinggi, ada 39 petani yang menyatakan bahwa hasil produksi usaha tani tebu termasuk pada kriteria rendah, dan ada 7 petani yang menyatakan bahwa hasil produksi usaha tani tebu termasuk pada kriteria sangat rendah. Terkait masalah produksi tidak terlepas dari biaya untuk saprodi (sarana produksi), jika menginginkan produksi komoditas yang tinggi maka faktor-faktor produksi seperti tenaga kerja perlu ditambah, pupuk juga ditambah.

\section{e. Implikasi Empiris}

Berdasarkan data empiris dari hasil penelitian menunjukkan bahwa secara bersama-sama tenaga kerja, modal, dan luas lahan berpengaruh positif dan signifikan terhadap produksi usaha tani tebu di Kecamatan Ngadiluwih dibuktikan dari hasil uji $F$ sebesar 10,748 yang memperoleh signifikansi 0,000 .

Hasil dari tabel summary, diperoleh nilai $R=0,591$ dan koefisien determinasi (Adjusted $\mathrm{R}$ square)sebesar 0,350. Hal ini menunjukkan pengertian bahwa produksi usaha tani tebu di Kecamatan Ngadiluwih Kabupaten Kediri (PUTT) dipengaruhi sebesar 35\% oleh variabel tenaga kerja (TK), variabel modal (M), dan luas lahan (LL), sedangkan sisanya $65 \%$ $(100 \%-35 \%=65 \%)$ dipengaruhi oleh faktor lain yang tidak dibahas dalam penelitian ini. Didalam produksi pertanian, faktor produksi memang menentukan besar kecilnya produksi yang akan diperoleh. Untuk menghasilkan produksi (output) yang optimal maka penggunaan faktor produksi tersebut dapat digabungkan. Dalam berbagai literature menunjukkan bahwa faktor produksi lahan, modal untuk membeli bibit, pupuk, obat-obatan, tenaga kerja dan aspek 
manajemen adalah faktor produksi terpenting diantara faktor produksi yang lain, seperti tingkat pendidikan, tingkat pendapatan, tingkat ketrampilan dan lainlain.

Bentuk pengaruh antara tenaga kerja, modal, dan luas lahan terhadap produksi usaha tani tebu di Kecamatan Ngadiluwih Kabupaten Kediri adalah pengaruh positif yang ditunjukkan dari koefisien regresi maupun koefisien korelasi yang bertanda positif. Dengan demikian dapat dijelaskan bahwa jika variabel tenaga kerja, modal, dan luas lahan ditingkatkan maka akan diikuti dengan meningkatnya produksi usaha tani padi sawah di Kecamatan Ngadiluwih Kabupaten Kediri dalam memproduksi hasil tani tebu dalam artian produksi akan naik atau bertambah. Dan sebaliknya, jika variabel tenaga kerja, modal dan luas lahan menurun maka akan diikuti dengan menurunnya produksi usaha tani tebu di Kecamatan Ngadiluwih Kabupaten Kediri.

\section{Kesimpulan}

Hasil penelitian berdasarkan perumusan masalah, tujuan dan hipotesis penelitian melalui proses pengujian yang tertuang pada bab sebelumnya, dapat disimpulkan sebagai berikut:

a. Tenaga kerja memiliki pengaruh positif terhadap produksi usaha tani tebu di Kecamatan Ngadiluwih Kabupaten Kediri. Pengaruh positif tersebut bermakna peningkatan tenaga kerja akan menyebabkan terjadinya peningkatan terhadap produksi usaha tani tebu, sebaliknya penurunan tenaga kerja berakibat menurunnya produksi usaha tani tebu.

b. Modal secara signifikan memiliki pengaruh positif terhadap produksi usaha tani tebu di Kecamatan Ngadiluwih Kabupaten Kediri. Pengaruh yang signifikan tersebut artinya peningkatan modal akan menyebabkan terjadinya peningkatan produksi usaha tani tebu, sebaliknya penurunan modal berakibat menurunnya produksi usaha tani tebu.

c. Luas lahan secara signifikan memiliki pengaruh positif terhadap produksi usaha tani tebu di Kecamatan
Ngadiluwih Kabupaten Kediri. Pengaruh yang signifikan tersebut artinya semakin luas lahan yang tersedia maka semakin meningkat pula produksi usaha tani tebu, dan berlaku sebaliknya.

d. Secara bersama-sama tenaga kerja, modal dan luas lahan berpengaruh positif terhadap produksi usaha tani tebu di Kecamatan Ngadiluwih Kabupaten Kediri.

e. Hasil analisis uji dominansi untuk mengetahui kontribusi efektif menunjukkan bahwa modal mempunyai kontribusi yang paling dominan dalam mempengaruhi produksi usaha tani tebu di Kecamatan Ngadiluwih Kabupaten Kediri.

\section{Daftar Pustaka}

Agustina, E.S. (2010). Analisis Efisiensi Faktor Produksi dan Pendapatan Usahatani Tebu, Studi Kasus di Desa Banjarejo, Kecamatan Pagelaran Kabupaten Malang.

Ali, Muhammad. 1992. Statistika Penelitian. Yogyakarta: BPFE

Anonymous (2005). Revitalisasi Industri Gula Jawa Timur. Surabaya: Dinas Perkebunan Jawa Timur.

Anonymous (2005). Standar Karakteristik Pertumbuhan Agronomis Tebu. Surabaya: Dinas Perkebunan Jawa Timur.

Anonymous. 2014. www.disbun.jatimprov.go.id/komodi ti_tebu.php

Anonymous. 2017. (http://elibrary.ub.ac.id/bitstream/12 3456789/26408/5/analisis-efisiensifaktorproduksi-dan-pendapatanusahatani-tebu-saccharumofficinarum(ringkasan).pdf

Arikunto, Suharsimi. 2006. Prosedur Penelitian (Suatu Pendekatan Praktik):

Suatu Pendekatan Praktek. Jakarta : Rineka Cipta.

BPS 2007. Kabupaten Kediri Dalam Angka. BPS Kabupaten Kediri.

Balitbangtan, 2007. Prospek dan Arah Pengembangan Agribisnis Tebu . Edisi Ke Dua. Badan Penelitian 
dan Pengembangan Pertanian. Departemen Pertanian.

Daniel, Mohar. 2014. Pengantar Ekonomi pertanian. Jakarta: PT Bumi Aksara.

Dewan Gula Indonesia. 2012, Taksasi dan realisasi produksi GKP dan giling tebu 2008-2013. Bahan Rapat Sekretariat

Effendi, H,. 2001. Budidaya Tebu Populasi Tinggi (Hight Density Planting) untuk Meningkatkan Produktivitas. Buletin IImiah INSTIPER 8(2):5260.

Fauzi, Achmad Faqih. 2007. Analisis Penggunaan Faktor Produksi Tanaman Tebu terhadap Pendapatan Petani. Jakarta: Unswagati

Ghozali, Imam. 2011. Aplikasi Analisis Multivariate dengan program SPSS. Semarang : Universitas Diponegoro.

Hadi, Soetrisno. 2014. Methodologi Reseach II.Yogyakarta : Andi Offset

Hakim, M. 2008. Tebu, Menuju Swasembada Gula Dengan 4 Pilar Trobosan. Emha Training Center \& Advisory. Bandung

Kementerian Pertanian. 2013. Laporan Data Kinerja Kementerian Pertanian Tahun 2004-2012. Jakarta: Kementerian Pertanian

Kompas. 2016. Dampak Peningkatan Tarif Impor Gula terhadap Pendapatan Petani Tebu.

Kusuma, Ardiansyah. 2010. Diskripsi Varietas Tebu PS 864, PS 865, Kidang Kencana. PT. Perkebunan Nusantara X (Persero). Surabaya.

Mulyana, W. 2001. Teori dan Praktek Cocok Tanam Tebu Dengan Segala Masalahnya. Aneka IImu, Semarang

Rahim, Abd dan Hastuti, Diah Retno. 2007. Pengantar teori dan kasus. Ekonomika Pertanian, Jakarta: Penebar Swadaya.

Prasetya, P. 2006. Handout IImu Usahatani. Surakarta : Fakultas Pertanian, Universitas Sebelas Maret.

Purwono, 2011. Efisiensi penggunaan air pada budi daya tebu di lahan kering. Thesis S3. Sekolah
Pascasarjana, Institut Pertanian Bogor.

Pusat Data Informasi Pertanian, 2010. Outlook komoditas perkebunan. Kementerian Pertanian RI.

Qudratullah, M.F. (2012). Analisis Regresi Terapan Teori, Contoh Kasus dan Aplikasi dengan SPSS. Yogyakarta: CV. Andi Offset.

Saleh, Mohammad. 2012. Faktor Yang Mempengaruhi Pendapatan Kelompok Petani Tebu di Desa Gunung Anyar Kecamatan Tape Kabupaten Bondowoso. Dalam Jurnal ISEI Jember Vol. 2 Nomor 1. Jember: Universitas Jember.

Sugiarta, S. 2007. Konsepsi Penataan Varietas dan Pengembangan Varietas Tebu Unggul dalam Program Pelatihan "Petugas Litbang Pabrik Gula P3GI. 15 hal. dalam Sekilas Info tentang Varietas Tebu Bina

Sugiyono. 2012. Metode Penelitian Kuantitatif Kualitatif dan $R \& D$. Bandung: CV Alfabeta.

Sumastuti, Efriyani. 2009. Analisis Pendapatan Keluarga Petani Tebu di Kabupaten Pekalongan. Dalam jurnal ilmu pertanian Vol. 5 Nomor 1. Yogjakarta: Sekolah Tinggi Penyuluhan Pertanian

Soekartawi. 2011. Agribisnis, Teori dan Aplikasinya. Jakarta: Rajawali Pers. . 2013. Prinsi-prinsip Dasar

Ekonomi Pertanian. Jakarta: Rajawali Pers. . 2012. Analisis Usahatani. Jakarta: Universitas Indonesia.

Tain, Anas. 2005. Buku Ajar Usahatani. Jurusan Aribisnis Fakultas Pertanian Peternakan Universitas Muhammadiyah Malang: Malang

Widarwati, Tutik. 2008. Analisis FaktorFaktor yang Mempengaruhi Produksi Gula di PG. Pagottan (Skripsi). Institut Pertanian Bogor: Bogor

Widjayanto, 2010. Pengelolaan tanaman tebu pada industri gula di PT. Kebon Agung. Makalah Seminar Balittas. Malang. 